\title{
STUDI KELAYAKAN PEMBUKAAN CABANG BANK SYARIAH DI KOTA BOGOR PROVINSI JAWA BARAT (STUDI DI BANK SYARIAH MANDIRI)
}

\section{FEASIBILITY STUDY OF ISLAMIC BANK BRANCH OPENING IN WEST JAVA BOGOR (STUDY IN BANK SHARIA MANDIRI)}

\author{
Maryanto'a; Ating Sukma $^{2 b}$ \\ Jurusan Ekonomi Islam Fakultas Ekonomi Islam Universitas Djuanda, Jl. Tol Ciawi No. 1, \\ Kotak Pos 35 Bogor 16720 \\ Jurusan Perbankan Syariah Fakultas Ekonomi Islam Universitas Djuanda, Jl. Tol Ciawi \\ No. 1, Kotak Pos 35 Bogor 16720
}

E-mail : 1amaryanto@unida.ac.id, 2batingjuanda@yahoo.com

(Diterima oleh Dewan Redaksi: 25-01-2016)

(Dipublikasikan oleh Dewan Redaksi: 01-06-2016)

\begin{abstract}
This research is focused to find out the feasibility study Islamic bank to open a branch in the city of Bogor, West Java Province. This research is expected to provide information on the feasibility of opening branches of Islamic banks, which include procedures for opening branches of Islamic banks, the standardization of opening branches and obstacles in opening branches. The method used is a qualitative and quantitative methods with techniques Miles and Huberman analysis. The feasibility study is the most important thing to do a company before doing business. With the feasibility study the company will know the strengths and weaknesses of the company. These results indicate that by using technical analysis Miles and Huberman known that the standardization of procedures and the opening of branches of Islamic banks are in accordance with Bank Indonesia Regulation (PBI), and the Bank Business Plan (RBB). By using SWOT analysis known location of the company's position in the future be in a position quadrant I, which means a strong company and potentially position.
\end{abstract}

Keywords: Feasibility study Islamic bank branch opening

\begin{abstract}
ABSTRAK
Penelitian ini difokuskan untuk mengetahui proses studi kelayakan pembukaan cabang bank syariah di Kota Bogor Provinsi Jawa Barat. Penelitian ini diharapkan dapat memberikan informasi tentang kelayakan pembukaan cabang bank syariah, yang meliputi prosedur pembukaan cabang bank syariah, standarisasi pembukaan cabang dan kendala-kendala dalam pembukaan cabang. Metode penelitian yang digunakan adalah metode kualitatif dan kuantitatif dengan teknik analisis Miles and Huberman. Studi kelayakan merupakan hal terpenting yang harus dilakukan sebuah perusahaan sebelum menjalankan usahanya. Dengan studi kelayakan perusahaan akan mengetahui kekuatan dan kelemahan yang dimiliki perusahaan. Hasil penelitian ini menunjukan bahwa dengan menggunakan analisis teknik Miles and Huberman diketahui bahwa prosedur dan standarisasi pembukaan cabang bank syariah sudah sesuai dengan
\end{abstract}


Peraturan Bank Indonesia (PBI), dan Rencana Bisnis Bank (RBB). Dengan menggunakan analisis SWOT diketahui letak posisi perusahaan dimasa yang akan datang berada pada posisi kuadran I yang artinya posisi perusahaan kuat dan berpeluang.

Kata Kunci : studi kelayakan pembukaan cabang bank syariah

Maryanto. 2015. Studi Kelayakan Pembukaan Cabang Bank Syariah Di Kota Bogor Provinsi Jawa Barat (Studi Di Bank Syariah Mandiri). (2): 243 - 255

\section{PENDAHULUAN}

Setelah berdirinya Bank Muamalat Indonesia (BMI) pada tahun 1992 sebagai pelopor berdirinya perbankan yang berlandaskan syariah, perbankan syariah Indonesia terus mengalami perkembangan secara pesat. Pada awalnya keberadaan bank syariah di Indonesia belum dikenal luas oleh masyarakat dan juga belum memperoleh perhatian yang besar dalam tatanan industri perbankan nasional. Hal ini terlihat pada landasan hukum operasional bank syariah yang digunakan hanya dikategorikan sebagai "bank dengan sistem bagi hasil", sehingga tidak melihat adanya rincian landasan hukum syariah dan jenis-jenis usaha yang diperbolehkan (Antonio,2001:26).

Keberadaan UU No. 7 tahun 1992 tentang perbankan menjadi tonggak legalitas diadopsinya perbankan syariah dalam sistem perbankan nasional, seiring berjalannya waktu perkembangan perekonomian yang senantiasa bergerak cepat sehingga perlu adanya peraturanperaturan baru mengenai sistem perbankan syariah. Pada tahun 1998, diterbitkan UU No. 10 tahun 1998 yang mengatur tentang bank syariah. Dalam Undang-Undang tersebut telah diatur secara terperinci landasan hukum dan kategori usaha-usaha yang dapat dijalankan oleh bank syariah.

Dengan mulai berlakunya UU No. 21 Tahun 2008 tentang perbankan syariah, perbankan syariah mendapat kesempatan yang lebih besar dalam melaksanakan kegiatan usaha, termasuk memberikan kesempatan kepada bank umum yang berbasis bunga (konvensional) untuk membuka layanan kantor bank yang khusus melakukan kegiatan operasionalnya berdasarkan prinsip syariah. (Sumber: Statistik Perbankan Syariah, 2014)

Pemberian kesempatan kepada bank konvensional untuk membuka kantor cabang berdasarkan prinsip syariah bertujuan untuk meningkatkan jaringan perbankan syariah yang dilakukan secara bersamaan dengan upaya pemberdayaan perbankan syariah yang sudah ada. Dengan upaya tersebut diharapkan akan mendorong perluasan jaringan perbankan syariah, pengembangan pasar uang antar bank syariah, peningkatan kualitas sumberdaya manusia, dan kinerja bank syariah yang akhirnya akan menunjang penguatan ekonomi yang lebih tangguh.

Bertambahnya jumlah bank akan berdampak pada cepatnya pertumbuhan perbankan syariah di Indonesia, namun semakin banyak bank yang berdiri dapat pula berdampak pada besarnya persaingan perbankan syariah yang tidak hanya terjadi pada bank syariah saja, namun terjadi pula pada bank konvensional yang mulai banyak membuka layanan syariah. Oleh karena itu, bank-bank syariah yang telah berjalan harus menciptakan produk-produk perbankan yang lebih inovatif,sehingga dapat menarik nasabah yang lebih besar lagi dan juga dapat bertahan di tengah munculnya para pesaing baru.

Untuk mengembangkan usahanya, bank syariah dapat membuka kantor cabangnya di berbagai daerah, akan tetapi 
terlebih dahulu perlu dilakukan analisis studi kelayakan, baik yang berasal dari dalam maupun dari luar bank. Dari hasil analisis tersebut bank dapat mendiagnosis lingkungan serta mengambil kebijakan strategis dalam pembukaan cabang bank syariah.

Dalam proses studi kelayakan diperlukan tahapan-tahapan yang sesuai agar tidak terjadi ketidaksesuaian. Tahapan-tahapan dalam pembuatan dan penilaian studi kelayakan bisnis hendaknya dilaksanakan secara benar dan lengkap, karena terdapat aspek-aspek yang harus dianalisis berdasarkan ketentuan yang telah ditetapkan. Tahapan analisis dalam studi kelayakan ini bertujuan untuk mempermudah pelaksanaan studi kelayakan dan keakuratan dalam penilaian (Sudaryono,2015: 33).

\section{MATERI DAN METODE}

\section{Jenis Dan Obyek Penelitian}

Penelitian yang digunakan dalam menganalisa studi kelayakan pembukaan cabang bank syariah di kota Bogor provinsi Jawa Barat ini merupakan penelitian deskriptif kualitatif. Jenis penelitian ini adalah studi kasus yang menggunakan metode survey, dengan teknik pengumpulan data melalui teknik wawancara, observasi dan studi pustaka, dengan menggunakan alat Miles and Huberman dan analisis SWOT.

\section{Sumber Data}

Adapun sumber data yang diperoleh dalam penelitian ini berasal dari data primer dan sekunder. Data primer merupakan data yang diambil secara langsung dari tempat penelitian atau lapangan, data primer dalam penelitian ini bersumber dari kuisioner dan wawancara dengan 1 responden atau narasumber dari salah satu lembaga keuangan syariah. Sedangkan data sekunder yaitu data pendukung yang diperoleh melalui dokumentasi dari literatur baik textbook, internet, jurnal, buku, majalah yang memiliki kaitan dengan penelitian ini (Trihantana,2014:14). Dalam penelitian ini data sekunder yang didapatkan berseumber dari internet, jurnal dan buku, dan data yang lainnya yang memiliki keterkaitan dengan penelitian ini.

\section{Populasi dan Sampel}

Populasi yang diambil dalam penelitian ini adalah Bank Umum Syariah yang berada di kota Bogor (Sugiyono, 2009: 215). Adapun sampelnya yaitu Bank Syariah Mandiri yang berada di kota Bogor(Sugiyono,2009:218).

\section{Teknik Pengumpulan Data}

Teknik pengumpulan data dalam penelitian ini dengan mengggunakan tiga metode/teknik, yaitu:

1. Teknik observasi adalah teknik yang digunakan untuk mengamati dan mencatat secara sistematis dari kejadian-kejadian yang ada. Metode ini merupakan pengumpulan data secara langsung dengan melakukan pengamatan di Bank Umum Syariah yang berada di kota Bogor.

2. Teknik wawancara yaitu melakukan proses tanya jawab atau interview secara langsung dengan praktisi pada lembaga Bank Umum Syariah yaitu Bank Mandiri Syariah yang telah ditentukan oleh peneliti.

3. Teknik kuesioner merupakan teknik pengumpulan data yang diperoleh dengan cara memberikan pertanyaan tertulis kepada responden untuk dijawab denganmemilih jawaban yang tersedia (Sugiono, 2007:135). Namun sebelumnya penulis meminta ketersediaan terlebih dahulu kepada responden untuk mengisi kuesioner. 
Prosedur dan Metode Analisis Data

1. Analisis Data Lapangan Model Miles And Huberman (Sugiyono,2009:247).

a. Reduksi Data

Data yang didapatkan dari hasil penelitian lapangan sangat kompleks mulai dari hasil observasi, wawancara dan kuesioner, maka perlu dilakukan analisis data melalui reduksi yaitu memilih hal-hal penting yang menjadi pokok dalam penelitian. Sehingga dengan demikian akan memudahkan peneliti dalam mengumpulkan data selanjutnya.

b. Penyajian Data

Setelah melakukan reduksi, langkah selanjutnya yaitu mendisplaykan data dengan cara membentuk uraian singkat, bagan, hubungan antar kategori dan sejenisnya. Hal ini akan mempermudah peneliti dalam memahami apa yang terjadi, dan merencanakan langkah berikutnya dari hasil pemahaman tersebut.

c. Penarikan kesimpulan dan verifikasi Penarikan kesimpulan pada tahap awal masih bersifat sementara, dan akan mengalami perubahan apabila tidak ditemukan bukti-bukti kuat yang dapat menunjang pada tahap pengumpulan data berikutnya, akan tetapi apabila kesimpulan awal tersebut terbukti valid dan konsisten maka kesimpulan yang dikemukakan merupakan kesimpulan yang kredibel.

2. Analisis SWOT

Analisis SWOT adalah suatu bentuk analisis yang dilakukan dengan cara mengidentifikasi berbagai faktor secara sistematis dalam usaha merumuskan strategi perusahaan. Strategi tersebut selalu berkaitan dengan pengembangan visi, misi, tujuan, strategi dan kebijakan perusahaan (Rangkuti, 2002:19). Analisis ini mengedepankan logika berfikir dengan cara memaksimalkan kekuatan $\begin{array}{lrr}\text { (Strenghts) } & \text { dan } & \text { peluang } \\ \text { (Oppurtunities) } & \text { serta } & \text { dapat }\end{array}$ meminimalkan kelemahan (Weakness) dan ancaman (Threats) yang dilakukan secara bersamaan.

Model Analisis SWOT membandingkan antara faktor internal dengan faktor eksternal. Faktor internal berupa kekuatan dan kelemahan bank yang dimasukkan dalam matrik yang disebut matrik faktor strategi internal atau IFAS (Internal Strategic Factor Analisis Summary). Sedangkan faktor eksternal yang menggambarkan peluang dan ancaman bank dimasukkan dalam matrik yang disebut matrik faktor strategi eksternal atau EFAS (Eksternal Strategic Factor Analisis Summary).

Setelah matrik kedua faktor tersebut selesai disusun, akan menemukan hasil yang selanjutnya akan dimasukkan dalam model kuantitatif, yaitu matrik SWOT yang berguna untuk merumuskan strategi kompetitif perusahaan (jurnal, Zuhrotun Nisak:2013).

\section{HASIL DAN PEMBAHASAN}

\section{Analisis Data Lapangan Model Miles And Huberman}

Analisis pertama yang digunakan peneliti adalah analisis model miles and huberman yaitu sebelum melakukan analisis pada tahap data reduction, data display dan conclusion drawing, peneliti terlebih dahulu akan mengumpulkan data (data collecting) atau informasi hasil interview yang diperoleh dari beberapa sumber-sumber serta dokumen-dokumen yang terkait dengan judul penelitian. Dengan hasil wawancara sebagai berikut:

1. Bagaimana Prosedur Pembukaan Kantor Cabang Bank Syariah Sebagaimana hasil diskusi antara peneliti dan narasumber, bahwa yang dilakukan Bank Syariah Mandiri dengan pertanyaan wawancara 
bagaimana prosedur pembukaan kantor cabang bank syariah adalah sebagai berikut:

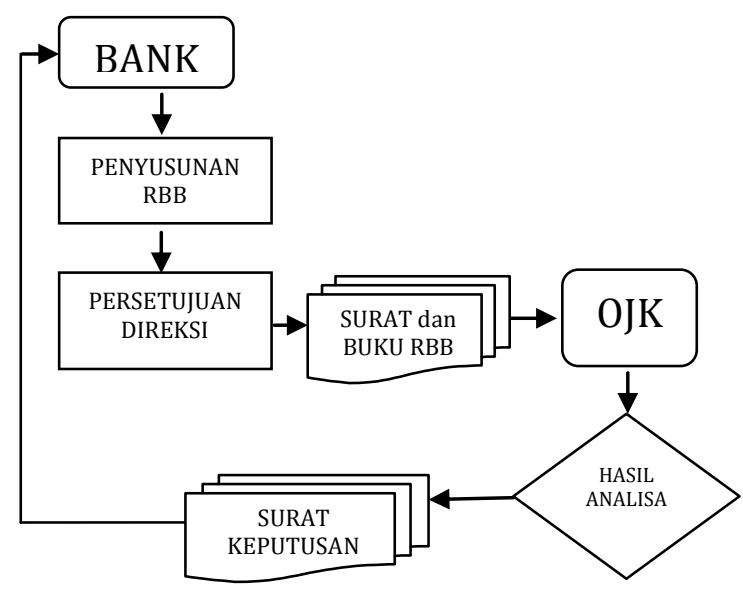

Gambar 1.

Prosedur Perizinan Pembukaan Kantor Cabang

Sumber : Bank Syariah Mandiri, 2015

Bank menyusun Rencana Bisnis Bank (RBB) dengan tujuan untuk memberikan gambaran tentang rencana kegiatan usaha bank baik dalam jangka pendek (satu tahun) maupun jangka menengah (tiga tahun), termasuk rencana untuk pembukaan outlet-outlet baru. Berdasarkan hasil wawancara dengan narasumber di Bank Syariah Mandiri, Rencana Bisnis Bank (RBB) termasuk dokumen rahasia, sehingga penulis tidak dapat memberikan keterangan lebih mendalam perihal RBB.

Bank membuat surat permohonan pembukaan outlet baru yang akan diajukan beserta buku RBB kepada OJK yang kemudian akan dianalisis oleh OJK. Setelah mendapat hasil analisis, 0JK mengirimkan surat keputusan kepada bank mengenai permohonan pembukaan outlet baru yang telah diajukan (Narasumber, Bank Syariah Mandiri:2015).

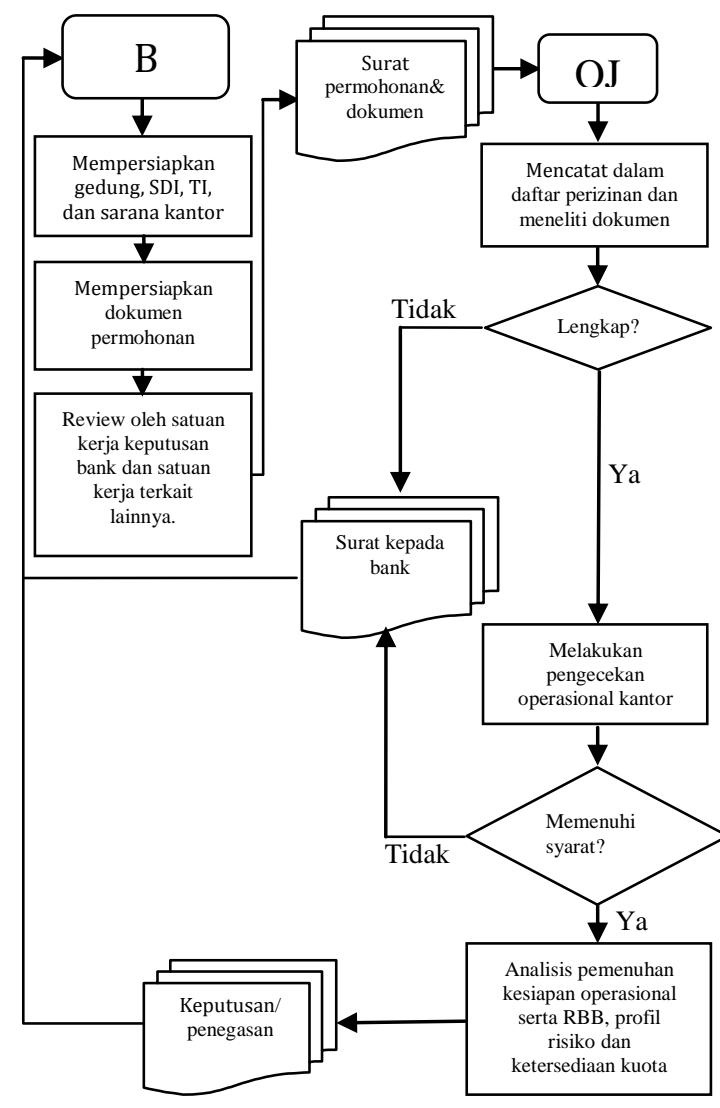

Gambar 2.

Proses Perizinan Pembukaan Kantor Cabang Sumber : Bank Syariah Manidiri, 2015.

Bank menerima surat keputusan dari OJK mengenai pengajuan permohonan pembukaan outlet baru yang akan dilaksanakan. Setelah mendapatkan persetujuan bank kemudian melanjutkan dengan melakukan persiapan-pesiapan yang dibutuhkan dalam proses pembukaan outlet baru seperti persiapan gedung, SDI, IT, dan sarana prasarana kantor serta mempersiapkan dokumen permohonan pembukaan outlet baru dan di review oleh satuan kerja keputusan bank dan satuan kerja pihak lainnya. kemudian diajukan kembali surat permohonan serta dokumen kesiapan pembukaan outlet baru ke 0JK.

OJK mencatat dalam daftar perizinan dan meneliti kelengkapan dokumendokumen yang diusulkan oleh bank, apabila terdapat ketidaksesuain 
dengan ketentuan maka OJK mengirim surat balasan kepada bank mengenai ketidaksesuaian yang telah didapati untuk segera dipenuhi oleh bank yang kemudian bank akan memulai proses seperti yang telah dilakukan sebelumnya.

Namun apabila surat permohonan dan dokumen yang diajukan memenuhi persyaratan maka OJK melaksanakan pengecekkan operasional kantor dan analisis pemenuhan kesiapan operasional serta RBB, profil risiko, dan ketersediaan kuota kantor. Kemudian memberikan keputusan/penegasan pembukaan outlet baru pada bank (Narasumber, Bank Syariah Mandiri:2015).

Sebagaimana penjelasan diatas bahwa dalam prosedur pembukaan cabang sesuai dengan RBB (Rencana Bisnis Bank) dan PBI (Peraturan Bank Indonesia) terkait Pembukaan Kantor Cabang, yaitu tertera pada :

a. Pasal 42

Dalam pasal tersebut dijelaskan bahwa pembukaan KC (Kantor Cabang) hanya dapat dilakukan atas perolehan izin dari Bank Indonesia.

b. Pasal 43

Setiap bank yang ingin membuka kantor cabang dapat mengajukan permohonan izin dari bank yang bersangkutan kepada Bank Indonesia disertai dengan dokumen pendukung (PBI/No 15//13/PBI/2013. BAB V) yaitu contoh format surat sebagaimana yang tertera dalam Lampiran 12 disertai dengan dokumen sebagai berikut: (SEBI.No.15/50/DPbS. Hal:3).

1) Daftar pemenuhan per-syaratan yang harus disediakan (compliance check list) dalam persiapan operasional yang telah dipastikan oleh satuan kerja kepatuhan meliputi: a) Daftar aktiva tetap dan inventaris

b) Susunan dan struktur organisasi

c) Bukti kepemilikan, penguasaan atau perjanjian sewa atau nota kesepakatan sewa menyewa gedung kantor.

d) Foto gedung kantor dan tata letak ruangan, termasuk ruang khasanah yang menunjukkan persiapan kantor Bank beroperasi.

e) Persiapan sumber daya manusia.

f) Persiapan jaringan telekomunikasi; dan

g) Formulir atau warkat yang akan digunakan dalam operasional.

h) Rencana penghimpunan dan penyaluran dana paling singkat selama 12 (dua belas) bulan beserta penjelasannya.

2) Hasil studi kelayakan yang telah dilakukan oleh bank bersangkutan dengan paling kurang memuat potensi ekonomi, peluang pasar, tingkat persaingan yang sehat antar bank dan unit usaha syariah, serta tingkat kejenuhan jumlah kantor bank dan kantor unit usaha syariah.

3) Persetujuan atau penolakan atas permohonan izin sebagaimana dimaksud pada ayat (1) diberikan Bank Indonesia dengan memper-timbangkan antara lain:
a) Kelengkapan dan kebenaran dokumen.
b) Analisis atas hasil studi kelayakan yang disampaikan oleh bank.
c) Analisis atas kemampuan bank, termasuk tingkat kesehatan, kecukupan



permodalan, dan profil risiko; dan
d) Analisis atas kajian sebagaimana dimaksud dalam Pasal 41A ayat (2).

4) Bank Indonesia dapat memeriksa kebenaran dokumen pendukung dan lainnya yang disampaikan serta persiapan pembukaan $\mathrm{KC}$ (Kantor Cabang).

5) Ketentuan lebih lanjut mengenai dokumen pendukung sebagaimana dimaksud pada ayat (1) diatur dengan Surat Edaran Bank Indonesia.

c. Pasal 44

1) Pelaksanaan pembukaan KC wajib dilakukan paling lama 30 (tiga puluh) hari terhitung sejak tanggal izin dari Bank Indonesia diterbitkan.

2) Pelaksanaan pembukaan $\mathrm{KC}$ sebagaimana dimaksud pada ayat (1) wajib dilaporkan oleh Bank kepada Bank Indonesia sesuai ketentuan Bank Indonesia yang mengatur mengenai laporan kantor pusat bank umum.

3) Apabila setelah jangka waktu sebagaimana dimaksud pada ayat (1), Bank tidak melaksanakan pembukaan $\mathrm{KC}$, maka izin pembukaan KC yang telah diberikan menjadi tidak berlaku. (PBI/No

15/13/PBI/2013.BAB V).

Strategi yang dijalankan oleh Bank Syariah Mandiri dalam pembukaan cabang bank yaitu strategi bisnis dan layanan sebaik-baiknya, yakni mencari keuntungan dan memberikan pelayanan yang berkualitas, dengan adanya pengembangan usaha diharapkan dapat menjangkau pangsa pasar yang lebih besar.

Peneliti melihat prosedur pembukaan cabang pada Bank Syariah Mandiri ini dari aspek hukumnya telah sesuai dengan peraturan yang dikeluarkan oleh Bank Indonesia sebagaimana yang telah dipaparkan di atas pada pasal 42 , pasal 43 dan pasal 44, yaitu Bank Syariah Mandiri sudah memenuhi syarat dalam proses perizinan pembukaan cabang baik dari segi bentuk badan usaha, bukti diri, tanda daftar perusahaan, izin mendirikan bangunan (IMB) dan lain sebagainya sesuai dengan ketentuan pembentukan perusahaan pada umumnya.

Adapun jika dilihat dari aspek keuangan sendiri yaitu Bank Syariah Mandiri ini tidak menargetkan pada nominal keuntungan berapa akan dibukanya cabang baru, dengan kata lain Bank Syariah Mandiri tidak menjadikan laba sebagai patokan dalam pembukaan cabang outlet baru, karena pada dasarnya pembukaan cabang-cabang baru sudah tercantum dalam RRB yang bersifat rahasia bagi umum.

Aspek pasar dan pemasaran yaitu seperti yang telah diketahui bahwa tata letak cabang Bank Mandiri Syariah di Bogor terletak pada perkotaan dan Bank Mandiri Syariah sendiri sudah menjadi bank syariah terbesar di Indonesia dan mempunyai strategi-strategi pasar yang bagus sehingga hal ini pula yang mampu menarik nasabah atau masyarakat untuk memilih Bank Mandiri Syariah.

2. Standarisasi kelayakan pembukaan kantor cabang Bank Syariah Mandiri di kota Bogor Provinsi Jawa Barat. Dari hasil wawancara Standarisasi pembukaan cabang pada Bank Syariah Mandiri ini mengacu pada peraturan bank Indonesia (PBI) tahun 2013 yang isinya adalah:

a. Dalam proses pembukaan cabang bank sesuai dengan PBI No 15/13/PBI/2013 yaitu Bank wajib mencantumkan rencana pembukaan, perubahan status, 
pemindahan alamat, dan/atau penutupan kantor Bank setahun ke depan dalam rencana bisnis Bank.

b. Rencana pembukaan, perubahan status, pemindahan alamat, dan/atau penutupan kantor Bank sebagaimana dimaksud pada ayat (1) wajib disertai dengan kajian yang paling kurang memuat:

1) Analisis kondisi keuangan, kesesuaian dengan strategi bisnis dan dampak terhadap proyeksi keuangan.

2) Mekanisme pengawasan dan penilaian kinerja kantor Bank.

3) Analisis secara menyeluruh mencakup antara lain kondisi perekonomian nasional, analisis risiko, dan analisis keuangan dan.

4) Rencana persiapan operasional antara lain sumber daya manusia, teknologi informasi, dan sarana penunjang lainnya.

c. Dalam rangka pembukaan, perubahan status, dan/atau pemindahan alamat kantor, bank wajib memenuhi ketentuan Bank Indonesia yang mengatur mengenai kegiatan usaha dan jaringan kantor berdasarkan modal inti.

d. Ketentuan lebih lanjut mengenai cakupan kajian sebagaimana dimaksud pada ayat (2) diatur dengan Surat Edaran Bank Indonesia 15//13/PBI/2013.Pasal 41A).

Jaringan kantor bank yang akan dibuka harus mendapatkan persetujuan dari Bank Indonesia. BI selaku pemegang otoritas perbankan dapat menyetujui atau menolak pembukaan jaringan kantor bank tersebut dengan melakukan pertimbangan terlebih dahulu. Pertimbangan tersebut dapat dilihat dari segi mikro dan makro ekonomi antara lain upaya pengembangan ekonomi daerah, perluasan lapangan kerja, kesesuaian dengan prioritas sektor pembangunan, perluasan akses keuangan bagi masyarakat berpenghasilan rendah dan produktif (financial inclusion), dan keberpihakan kepada kepentingan nasional.

3. Kendala yang dihadapi dalam pembukaan cabang Bank Syariah Mandiri di kota Bogor Provinsi Jawa Barat.

Kendala yang dihadapi dalam proses pembukaan cabang ini diantaranya ialah dalam proses pencarian gedung yang sesuai dengan kriteria baik terkait luas gedung yang akan ditempati, status kepemilikan gedung, maupun kesepakatan kontrak antara bank dan pemilik gedung apabila gedung tersebut akan disewa oleh bank, ketersediaan SDM yang ahli dalam bidang perbankan yang masih minim khususnya di wilayah Indonesia timur (Narasumber:2015).

Pada prosedur pembukaan cabang dalam proses perizinan terhadap Bank Indonesia, bank yang akan melakukan pembukaan cabang harus menyerahkan dokumen-dokumen yang terkait seperti daftar aktiva tetap dan inventaris, susunan dan struktur organisasi, bukti kepemilikan, penguasaan atau perjanjian, sewa atau nota kesepakatan sewa menyewa gedung kantor, foto gedung kantor dan tata letak ruangan, termasuk ruang khasanah yang menunjukkan persiapan kantor Bank beroperasi, persiapan sumber daya manusia, persiapan jaringan telekomunikasi dan formulir atau warkat yang akan digunakan dalam operasional.

\section{Uji Analisis SWOT}

Analisis SWOT dilakukan untuk mengklasifikasikan kondisi internal dan eksternal yang terlihat sebagai inputan untuk perancangan proses, sehingga dengan proses yang sudah dirancang dapat berjalan dengan optimal, efektif dan efisien. 
Analisis SWOT ditujukan untuk pembuatan strategi dalam melaksanakan aktivitas perusahaan dengan mengklasifikasikan kondisi perusahaan. Adapun analisis SWOT pada penelitian ini menggunakan pendekatan kuantitatif analisis SWOT yaitu menghitung keseluruhan hasil analisis SWOT agar memperoleh posisi organisasi yang pasti, sehingga dapat dengan mudah untuk diidentifikasi.

Menentukanbobot pada setiap variabel yang telah ditentukan.

Tabel 1 Penentuan Bobot IFAS (Internal Strategic Factors Summary)

\begin{tabular}{|c|c|c|c|}
\hline No & Faktor Strategi Internal & \multirow{2}{*}{\multicolumn{2}{|c|}{ Bobot }} \\
\hline \multicolumn{2}{|r|}{ Kekuatan (Strength) } & & \\
\hline 1 & $\begin{array}{l}\text { Proses pembukaan kantor cabang } \\
\text { sesuai dengan PBI }\end{array}$ & 9 & 0,11 \\
\hline 2 & $\begin{array}{l}\text { Dewan perusahaan terdiri dari } \\
\text { dewan komisaris dan dewan } \\
\text { pengawas }\end{array}$ & 9 & 0,11 \\
\hline 3 & $\begin{array}{l}\text { Lokasi yang strategis di tengah } \\
\text { kota }\end{array}$ & 7 & 0,08 \\
\hline 4 & $\begin{array}{l}\text { SDM tersedia sebelum } \\
\text { pembukaan cabang di lakukan }\end{array}$ & 8 & 0,1 \\
\hline 5 & $\begin{array}{l}\text { Sumber daya manusia BSM } \\
\text { professional dan sepenuhnya } \\
\text { mengerti oprasional perbankan }\end{array}$ & 9 & 0,11 \\
\hline 6 & $\begin{array}{l}\text { Adanya pemngembangan SDM } \\
\text { untuk jenjang karir }\end{array}$ & 7 & 0,08 \\
\hline 7 & $\begin{array}{l}\text { Identitas sebagai bank syariah } \\
\text { yang melekat }\end{array}$ & 7 & 0,08 \\
\hline \multicolumn{4}{|c|}{ Kelemahan (Weakness) } \\
\hline 1 & $\begin{array}{l}\text { Pencarian gedung yang sesuai } \\
\text { dengan kriteria kebutuhan bank }\end{array}$ & 8 & 0,1 \\
\hline 2 & $\begin{array}{l}\text { Adanya direktur yang memegang } \\
\text { jabatan rangkap yang berbeda } \\
\text { bidang }\end{array}$ & 1 & 0,01 \\
\hline 3 & $\begin{array}{l}\text { Sulit mendapatkan SDM yang } \\
\text { kompeten dalam bidang } \\
\text { perbankan syariah }\end{array}$ & 5 & 0,06 \\
\hline 4 & $\begin{array}{l}\text { Butuh penyesuaian dan pelatihan } \\
\text { bagi karyawan baru }\end{array}$ & 9 & 0,11 \\
\hline 5 & $\begin{array}{l}\text { Image masyarakat bank sebagai } \\
\text { bank yang diperuntukkan hanya } \\
\text { untuk orang Islam }\end{array}$ & 4 & 0,05 \\
\hline & Total & & 1,00 \\
\hline No & Faktor Strategi Eksternal & \multirow{2}{*}{\multicolumn{2}{|c|}{ Bobot }} \\
\hline & Peluang (Opportunity) & & \\
\hline 1 & Pertumbuhan perbankan syariah & 8 & 0,12 \\
\hline 2 & $\begin{array}{l}\text { Perkembangan teknologi yang } \\
\text { sangat pesat dalam bidang IT }\end{array}$ & 9 & 0,13 \\
\hline 3 & $\begin{array}{l}\text { Masyarakat Indonesia yang } \\
\text { mayoritas agama Islam }\end{array}$ & 9 & 0,13 \\
\hline 4 & $\begin{array}{l}\text { Tidak dikhususkan untuk } \\
\text { masyarakat yang beragama Islam }\end{array}$ & 8 & 0,12 \\
\hline 5 & Mendapat dukungan penuh dari & 9 & 0,13 \\
\hline
\end{tabular}

\begin{tabular}{|r|l|r|r|}
\hline & pemilik modal & & \\
\hline \multicolumn{1}{|l|}{ Ancaman (Threat) } & & \\
\hline & Semakin banyaknya pesaing & 8 & 0,12 \\
\hline & $\begin{array}{l}\text { Pesaing memiliki teknologi yang } \\
\text { lebih canggih }\end{array}$ & 4 & 0,05 \\
\hline $\begin{array}{l}\text { Banyaknya produk yang sejenis } \\
\text { menawarkan banyak keunggulan }\end{array}$ & 6 & 0,08 \\
\hline $\begin{array}{l}\text { Banyaknya pilihan produk dari } \\
\text { bank lain Total }\end{array}$ & 8 & 0,12 \\
\hline \multicolumn{2}{|c|}{ Total }
\end{tabular}

Sumber: Hasi penelitian (data diolah, 2015)

Pemberian bobot pada masing-masing faktor ini diberikan oleh responden dengan ketentuan penilaian terhadap satu poin faktor adalah dengan membandingkan tingkat kepentingan-nya dengan faktor lain. penilaian bobot berkisaran antara 1,0 (sangat penting sampai dengan 0,0 (tidak penting).

Menentukan skala dengan ukuran skala huruf $\mathrm{a}=$ sangat baik dengan penilaian angka (4), huruf $b=$ baik dengan penilaian angka (3), huruf $c=$ cukup dengan penilaian angka (2), dan huruf $d=$ buruk dengan penilaian angka sebesar (1). Penberian nilai skala untuk faktor kekuatan dan peluang bersifat positif (kekuatan atau peluang semakin besar diberi skala +4 tetapi jika kekuatan atau peluangnya kecil maka diberi skala +1 ). Pemberian nilai skala kelemahan dan ancaman bersifat kebalikannya misalnya, jika nilai kelemahan atau ancaman sangat besar maka skala yang diberikan adalah 1 sebaliknya jika nilai kelemahan dan ancamannya sedikit maka skala yang diberikan adalah 4 .

Tabel 2 Penentuan Skala

\begin{tabular}{|c|l|c|c|c|}
\hline No & \multicolumn{1}{|c|}{$\begin{array}{c}\text { Faktor Strategis } \\
\text { Internal }\end{array}$} & Bobot & Skala & B x S \\
\hline $\mathbf{1}$ & Kekuatan (Strength) & & & \\
\hline $\mathbf{1}$ & $\begin{array}{l}\text { Proses pembukaan } \\
\text { kantor cabang sesuai } \\
\text { dengan PBI }\end{array}$ & 0,11 & 4 & 0,44 \\
\hline $\mathbf{2}$ & $\begin{array}{l}\text { Dewan perusahaan } \\
\text { terdiri dari dewan } \\
\text { komisaris dan dewan } \\
\text { pengawas }\end{array}$ & 0,11 & 4 & 0,44 \\
\hline $\mathbf{3}$ & $\begin{array}{l}\text { Lokasi yang strategis } \\
\text { di tengah kota }\end{array}$ & 0,08 & 3 & 0,24 \\
\hline $\mathbf{4}$ & $\begin{array}{l}\text { SDM tersedia } \\
\text { sebelum pembukaan } \\
\text { cabang di lakukan }\end{array}$ & 0,1 & 2 & 0,2 \\
\hline $\mathbf{5}$ & Sumber daya & 0,11 & 2 & 0,22 \\
\hline
\end{tabular}




\begin{tabular}{|c|c|c|c|c|}
\hline & \begin{tabular}{|l|} 
manusia BSM \\
professional dan \\
sepenuhnya mengerti \\
oprasional \\
perbankan \\
\end{tabular} & & & \\
\hline 6 & $\begin{array}{l}\text { Adanya } \\
\text { pemngembangan } \\
\text { SDM untuk jenjang } \\
\text { karir } \\
\end{array}$ & 0,08 & 3 & 0,24 \\
\hline 7 & $\begin{array}{l}\text { Identitas sebagai } \\
\text { bank syariah yang } \\
\text { melekat }\end{array}$ & 0,08 & 4 & 0,32 \\
\hline & Total Kekuatan & & & 2,1 \\
\hline No & $\begin{array}{l}\text { Kelemahan } \\
\text { (Weakness) }\end{array}$ & Bobot & Skala & B $\times S$ \\
\hline & $\begin{array}{l}\text { Pencarian gedung } \\
\text { yang sesuai dengan } \\
\text { kriteria kebutuhan } \\
\text { bank }\end{array}$ & 0,1 & 2 & 0,2 \\
\hline & $\begin{array}{l}\text { Adanya direktur yang } \\
\text { memegang jabatan } \\
\text { rangkap yang } \\
\text { berbeda bidang }\end{array}$ & 0,01 & 4 & 0,04 \\
\hline & $\begin{array}{l}\text { Sulit mendapatkan } \\
\text { SDM yang kompeten } \\
\text { dalam bidang } \\
\text { perbankan syariah } \\
\end{array}$ & 0,06 & 3 & 0,18 \\
\hline & $\begin{array}{l}\text { Butuh penyesuaian } \\
\text { dan pelatihan bagi } \\
\text { karyawan baru }\end{array}$ & 0,11 & 1 & 0,11 \\
\hline & $\begin{array}{l}\text { Image masyarakat } \\
\text { bank sebagai bank } \\
\text { yang diperuntukkan } \\
\text { hanya untuk orang } \\
\text { Islam }\end{array}$ & 0,05 & 3 & 0,15 \\
\hline & Total Kelemahan & & & 0.68 \\
\hline No & $\begin{array}{c}\text { Faktor Strategis } \\
\text { External }\end{array}$ & Bobot & Skala & B $\times S$ \\
\hline \multicolumn{5}{|c|}{ Peluang (Opportunity) } \\
\hline 1 & $\begin{array}{l}\text { Pertumbuhan } \\
\text { perbankan syariah }\end{array}$ & 0,12 & 3 & 0,36 \\
\hline 2 & $\begin{array}{l}\text { Perkembangan } \\
\text { teknologi yang sangat } \\
\text { pesat dalam bidang } \\
\text { IT }\end{array}$ & 0,13 & 3 & 0,39 \\
\hline 3 & $\begin{array}{l}\text { Masyarakat } \\
\text { Indonesia yang } \\
\text { mayoritas agama } \\
\text { Islam }\end{array}$ & 0,13 & 4 & 0,52 \\
\hline 4 & $\begin{array}{l}\text { Tidak dikhususkan } \\
\text { untuk masyarakat } \\
\text { yang beragama Islam }\end{array}$ & 0,12 & 4 & 0,48 \\
\hline 5 & $\begin{array}{l}\text { Mendapat dukungan } \\
\text { penuh dari pemilik } \\
\text { modal }\end{array}$ & 0,13 & 4 & 0,52 \\
\hline & Total peluang & & & 2,27 \\
\hline \multicolumn{5}{|c|}{ Ancaman (Threat) } \\
\hline 1 & $\begin{array}{l}\text { Semakin banyaknya } \\
\text { pesaing }\end{array}$ & 0,12 & 2 & 0,24 \\
\hline 2 & $\begin{array}{l}\text { Pesaing memiliki } \\
\text { teknologi yang lebih } \\
\text { canggih }\end{array}$ & 0,05 & 3 & 0,15 \\
\hline 3 & $\begin{array}{l}\text { Banyaknya produk } \\
\text { yang sejemis } \\
\text { menawarkan banyak }\end{array}$ & 0,08 & 3 & 0,24 \\
\hline
\end{tabular}

\begin{tabular}{|l|l|r|r|r|}
\hline & keunggulan & & & \\
\hline 4 & $\begin{array}{l}\text { Banyaknya pilihan } \\
\text { produk dari bank lain }\end{array}$ & 0,12 & 2 & 0,24 \\
\hline \multicolumn{2}{|l|}{ Total Ancaman } & & & 0,87 \\
\hline
\end{tabular}

Sumber : Hasil Penelitian (data diolah, 2015)

Masing-masing faktor diberikan tingkat rating atau skala dari 4 (sangat baik) sampai dengan 1 (buruk). Adapun pada penelitian iini proses penentuan skala ditentukan langsung dengan responden, ukuran skala pada masingmasing faktor mempengaruhi tingkat kepentingan variabel terhadap perusahaan.

Membuat matriks dari jumlah masingmasing SWOT untuk mengetahui dimana posisi perusahaan, sebelum

menentukan matriks agar mengetahui posisi perusahaan maka harus dilakukan penentuan jumlah waight scor (terbobot) dapat dilihat pada tabel dibawah ini.

Tabel 3 Perhitungan analisis SWOT

\begin{tabular}{|c|c|c|c|c|}
\hline No & $\begin{array}{c}\text { Faktor Strategis } \\
\text { Internal }\end{array}$ & Bobot & Skala & B $\times S$ \\
\hline \multicolumn{5}{|c|}{ Kekuatan (Strength) } \\
\hline 1 & $\begin{array}{l}\text { Proses pembukaan } \\
\text { kantor cabang sesuai } \\
\text { dengan PBI }\end{array}$ & 0,11 & 4 & 0,44 \\
\hline 2 & $\begin{array}{l}\text { Dewan perusahaan } \\
\text { terdiri dari dewan } \\
\text { komisaris dan dewan } \\
\text { pengawas }\end{array}$ & 0,11 & 4 & 0,44 \\
\hline 3 & $\begin{array}{l}\text { Lokasi yang strategis } \\
\text { di tengah kota }\end{array}$ & 0,08 & 3 & 0,24 \\
\hline 4 & $\begin{array}{l}\text { SDM tersedia } \\
\text { sebelum pembukaan } \\
\text { cabang di lakukan }\end{array}$ & 0,1 & 2 & 0,20 \\
\hline 5 & $\begin{array}{l}\text { Sumber daya } \\
\text { manusia BSM } \\
\text { professional dan } \\
\text { sepenuhnya mengerti } \\
\text { oprasional } \\
\text { perbankan }\end{array}$ & 0,11 & 2 & 0,22 \\
\hline 6 & $\begin{array}{l}\text { Adanya } \\
\text { pemngembangan } \\
\text { SDM untuk jenjang } \\
\text { karir }\end{array}$ & 0,08 & 3 & 0,24 \\
\hline 7 & $\begin{array}{l}\text { Identitas sebagai } \\
\text { bank syariah yang } \\
\text { melekat }\end{array}$ & 0,08 & 4 & 0,32 \\
\hline \multicolumn{2}{|r|}{ Total Kekuatan } & & & 2,1 \\
\hline \multirow[t]{2}{*}{ No } & $\begin{array}{l}\text { Kelemahan } \\
\text { (Weakness) }\end{array}$ & Bobot & Skala & B $\times S$ \\
\hline & $\begin{array}{l}\text { Pencarian gedung } \\
\text { yang sesuai dengan } \\
\text { kriteria kebutuhan } \\
\text { bank }\end{array}$ & 0,1 & 2 & 0,20 \\
\hline
\end{tabular}




\begin{tabular}{|c|c|c|c|c|}
\hline & $\begin{array}{l}\text { Adanya direktur yang } \\
\text { memegang jabatan } \\
\text { rangkap yang } \\
\text { berbeda bidang }\end{array}$ & 0,01 & 4 & 0,04 \\
\hline & $\begin{array}{l}\text { Sulit mendapatkan } \\
\text { SDM yang kompeten } \\
\text { dalam bidang } \\
\text { perbankan syariah }\end{array}$ & 0,06 & 3 & 0,18 \\
\hline & $\begin{array}{l}\text { Butuh penyesuaian } \\
\text { dan pelatihan bagi } \\
\text { karyawan baru }\end{array}$ & 0,11 & 1 & 0,11 \\
\hline & $\begin{array}{l}\text { Image masyarakat } \\
\text { bank sebagai bank } \\
\text { yang diperuntukkan } \\
\text { hanya untuk orang } \\
\text { Islam }\end{array}$ & 0,05 & 3 & 0,15 \\
\hline & Total Kelemahan & & & 0.68 \\
\hline \multicolumn{5}{|c|}{$\begin{array}{l}\text { Nilai } x \text { adalah selisih total kekuatan - total } \\
\text { kelemahan. } \\
x=2,1-0,68=1,42 \text {. Jadi nilai } x \text { adalah } 1,42\end{array}$} \\
\hline No & $\begin{array}{l}\text { Faktor Strategis } \\
\text { External }\end{array}$ & Bobot & Skala & B $\times S$ \\
\hline \multicolumn{5}{|c|}{ Peluang (Opportunity) } \\
\hline 1 & $\begin{array}{l}\text { Pertumbuhan } \\
\text { perbankan syariah }\end{array}$ & 0,12 & 3 & 0,36 \\
\hline 2 & $\begin{array}{l}\text { Perkembangan } \\
\text { teknologi yang sangat } \\
\text { pesat dalam bidang } \\
\text { IT }\end{array}$ & 0,13 & 3 & 0,39 \\
\hline 3 & $\begin{array}{l}\text { Masyarakat } \\
\text { Indonesia yang } \\
\text { mayoritas agama } \\
\text { Islam }\end{array}$ & 0,13 & 4 & 0,52 \\
\hline 4 & $\begin{array}{l}\text { Tidak dikhususkan } \\
\text { untuk masyarakat } \\
\text { yang beragama Islam }\end{array}$ & 0,12 & 4 & 0,48 \\
\hline 5 & $\begin{array}{l}\text { Mendapat dukungan } \\
\text { penuh dari pemilik } \\
\text { modal }\end{array}$ & 0,13 & 4 & 0,52 \\
\hline & & & & 2,27 \\
\hline \multicolumn{5}{|c|}{ Ancaman (Threat) } \\
\hline 1 & $\begin{array}{l}\text { Semakin banyaknya } \\
\text { pesaing }\end{array}$ & 0,12 & 2 & 0,24 \\
\hline 2 & $\begin{array}{l}\text { Pesaing memiliki } \\
\text { teknologi yang lebih } \\
\text { canggih }\end{array}$ & 0,05 & 3 & 0,15 \\
\hline 3 & $\begin{array}{l}\text { Banyaknya produk } \\
\text { yang sejemis } \\
\text { menawarkan banyak } \\
\text { keunggulan }\end{array}$ & 0,08 & 3 & 0,24 \\
\hline 4 & $\begin{array}{l}\text { Banyaknya pilihan } \\
\text { produk dari bank lain }\end{array}$ & 0,12 & 2 & 0,24 \\
\hline \multicolumn{2}{|r|}{ Total Ancaman } & & & 0,87 \\
\hline
\end{tabular}

Nilai y adalah selisih total peluang - total ancaman. $y=2,27-0,87=1,4$. Jadi nilai $y$ adalah 1,4

Sumber : Hasil Penelitian (data diolah, 2015)

Setiap skor dari kekuatan, kelemaham, peluang dan ancaman dijumlahkan secara terpisah, maka kita menentukan kordinat grafik analisis $(\mathrm{X}, \mathrm{Y})$ untuk mengetahui dimana posisi perusahaan. Untuk kordinat $(\mathrm{X})$ diisi dengan bagian jumlah skor dari kekuatan dan jumlah kelemahan, sedangkan kordinat (Y) diisi dengan dengan bagian jumlah skor peluang dan ancaman seperti yang dapat dilihat pada gambar dibwah ini.

Untuk lebih mengetahui sebenarnya dimana letak atau posisi perusahaan maka harus menentukan kordinat $\mathrm{x}$ grafik ke-2 maka kordinat $\mathrm{x}$ didapat hasil dari penjumlahan kekuatan dan kelemahan, begitupun dengan kordinat y medapat hasil dari penjumlahan peluang dan kekuatan.

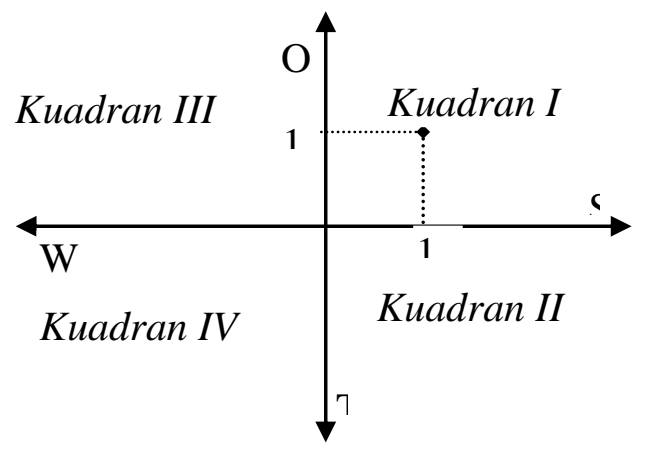

Gambar 1

Kuadran SWOT

Sumber: Hasil Penelitian (Data Diolah, 2015)

SWOT yang dapat dijelaskan sebagai berkut:

1. Kuadran I

Posisi ini memberikan tanda bahwa perusahaan tersebut kuat dan berpeluang. Selain itu, rekomendasi strategi yang diberikan progresif, artinya perusahaan berada dalam kondisi prima dan mantap sehingga memiliki kemungkinan yang besar untuk terus melakukan ekspansi, meningkatkan pertumbuhan, dan meraih kemajuan di masa mendatang secara maksimal.

2. Kuadran II

Dalam posisi kedua ini menandakan bahwa perusahaan tersebut dalam keadaan kuat namun menghadapi tantangan yang sangat besar. Sehingga rekomendasi strategi yang dapat diberikan adalah diverifikasi strategi, artinya perusahaan akan mengalami banyak kesulitan untuk terus berputar 
apabila hanya mengandalkan dan bertumpu pada strategi sebelumnya. Oleh karenanya, perusahaan disarankan untuk memperbanyak ragam strategi taktisnya.

3. Kuadran III

Posisi ketiga dalam kuadran ini menunjukkan sebuah perusahaan yang lemah namun memiliki peluang yang sangat besar. Dengan demikian, rekomendasi yang diberikan kepada perusahaan tersebut adalah ubah strategi, artinya perusahaan tersebut disarankan untuk merubah strategi sebelumnya yang pernah dijalankan, karena dikhawatirkan akan sulit untuk mengambil peluang yang telah ada, sehingga disarankan untuk selalu memperbaiki kinerja perusahaan.

4. Kuadran IV

Posisi terakhir dalam kuadran ini menandakan sebuah perusahaan berada dalam kondisi lemah dan menghadapi tantangan besar. Rekomendasi yang dapat disampaikan berupa strategi bertahan, yang memiliki arti bahwa kondisi internal perusahaan berada pada pilihan dilematis. Oleh karena itu, perusahaan disarankan untuk menggunakan strategi baru, mengendali-kan kinerja internal agar tidak semakin terperosok. Strategi ini dipertahankan sambil terus berupaya membenahi diri.

Jika kita melihat gambar diatas yang merupakan hasil dari penelitian analisis kuadran SWOT yang menunjukan keberadaannya pada tingkat (kuadran I) yang artinya posisi perusahaan tersebut dalam keadaan kuat dan berpeluang sehingga memiliki kemungkinan untuk terus melakukan ekspansi, meningkatkan pertumbuhan dan meraih kemajuan secara maksimal.

\section{KESIMPULAN DAN IMPLIKASI}

1. Prosedur pembukaan cabang bank pada Bank Syariah Mandiri mengacu pada Peraturan Bank Indonesia No. 12/21/PBI/2010 tentang Rencana Bisnis Bank dan Peraturan Bank Indonesia No. 15/13/PBI/2013 dimulai dari penyusunan RBB sampai dengan pembukaan kantor cabang.

2. Standarisasi pembukaan cabang Bank pada Bank Syariah Mandiri mengacu pada Peraturan Bank Indonesia No. 15/13/2013. Yaitu bank wajib mencantumkan rencana pembukaan, perubahan status, pemindahan alamat, dan/atau penutupan kantor bank setahun kedepan dalam Rencana Bisnis Bank serta wajib menyertakan kajian yang memuat analisis kondisi keuangan dan kondisi perekonomian nasional serta analisis risiko, mekanisme pengawasan, penilaian kinerja kantor bank, dan rencana persiapan operasional bank.

3. Kendala-kendala yang dihadapi Bank Syariah Mandiri dalam pembukaan cabang bank adalah pencarian gedung yang sesuai dengan kriteria bank terkait luas gedung yang akan ditempati, status kepemilikan gedung, dan kesepakatan kontrak sewa antara bank dan pemilik gedung.

\section{DAFTAR PUSTAKA}

Basrowi, suwandi, 2008, Memahami Penelitian Kualitatif, Rineka Cipta, Jakarta : PT Asdi Mahastya.

Rangkuti, Freddy, 2002, Analisis SWOT Teknik Membedah Kasus Bisnis, Jakarta, PT Gramedia Pustaka Utama.

Republik Indonesia, Peraturan Bank Indonesia Nomor: 12/ 21 /Pbi/2010 Tentang Rencana Bisnis Bank, di unduh pada tanggal 13/10/2015. 22:34Statistik Perbankan Syariah Desember 2014. Nomor : 14/26/Pbi/2012 Tentang Kegiatan Usaha Dan Jaringan Kantor 
Berdasarkan Modal Inti Bank, di unduh pada tanggal 13/10/2015. 22:34Subagyo, Ahmad, 2008, Studi

Kelayakan Teori Dan Aplikasi, Jakarta : pencetak PT Gramedia. Nomor : 15/13/PBI/2013 Tentang Perubahan Atas Peraturan Bank Indonesia Nomor 11/3/Pbi/2009 Tentang Bank Umum Syariah, di unduh pada tanggal 13/10/2015. 22:35.

Sugiyono,2007, Metode Penelitian Bisnis, Bandung : Alfabeta.

Sudaryono, 2009, Studi Kelayakan Bisnis Teori, Analisa, Dan Eknik Penyusunan Proposal, Jakarta Pusat : Lentera Ilmu Cendekia.

Syafi'I Antonio, Muhammad, 2001, Bank Syariah Dari Teori Ke Praktik, Jakarta : Gema Insani.

Trihantana, Rully, 2015, Model Penerapan Profit Equalization Reserve (2015) pada Lembaga Keuangan Syariah di Indonesia. Bogor: Universitas Djuanda Zuhrotun,Nisak,http://journal.unisla.ac.id /pdf/12922013/4.pdfAnalisis SWOT Untuk Menentukan Strategi Kompetitif. 